person, and not relegated, as is too often the case, to the fanciful manipulation of the patient.

St. Charles-square, W.

\section{NOTES ON TWO CASES OF TETANUS; RECOVERY.} By EDGar Swindells, L.R.C.P. Lond., M.R.C.S. EnG.

RECOVERY from tetanus is so extremely rare-the mortality being, I believe, about 90 per cent.- - that I have thought it worth while to record the two following cases. Both demonstrate the value of chloral hydrate in this condition.

CASE 1.-'The patient was a lad sixteen years of age. Three months before the date of the attack, whilst engaged in his duty - viz, that of attending to horses-he received an injury from a horse treading on the left foot. No notice was taken of it beyond the administration of domestic remedies. Ever since the accident the patient's mother noticed that he seemed to have difficulty in swallowing. He also complained of a "stiff neck." On the evening of Wednesday, June 12th, 1895, I received an urgent summons to see the patient. I found him lying in bed with strong tetanic contractions affecting all the muscles of the body. There were marked opisthotonos and risus sardonicus. The muscles of the neck were firmly contracted and felt as hard as iron (the patient was a powerfully - built young fellow). The masseters were also firmly contracted. The jaws were completely and firmly closed, and the tongue could not be protruded. The bowels were confined. The patient complained of pain and stiffness of the neck and down the spine. On making a thorough examination to ascertain the cause I found an ecchymosis under the nail of the left big toe. There was no other mark of injury all over the bady. I at once ordered the patient to be kept perfectly quiet, the room to be darkened, and liquid nourishment to be given at frequently repeated intervals. I prescribed ten orains of chloral hydrate every two hours. On the 13th I found the patient sitting up in bed. He stated that he could not lie down voluntarily; when he tried to do so he fell back. He said he felt better. There had been no more convulsions of the muscles of the back. There were still the risus sardonicus, trismus, and pain and stiffness of the neck. The head was kept bent forward, the eyes looking straight in front; he was unable to turn his head to either side. On the 14th there had been a return of the tetanic contractions of the muscles of the back since the day preceding. On the 15th the patient said he felt better. There had been no return of the opisthotonos. On July 7th the risus sardonicus had nuite disappeared, as also the trismus, though there were still considerable pain and stiffness of the neck. The patient was allowed to sit up a little time. On the 17th the pain and stiffness of the neck had quite clisappeared. The patient is now walking about feeling as well as ever.

CAss 2.-About three years ago I attended a little girl aged ten years who was suffering from well-marked tetanic symptoms. The condition in this case was idiopathic in origin. There was no history of injury, and no sign of wound or bruise of any kind. I gave her five grains of chloral hydrate every two hours. On the fourteenth day, as the tetanic symptoms had all disappeared, I stopped the chloral, when the symptoms immediately returned with increased severity. On renewed and continued exhibition of the drug they all disappeared again, and the patient completely recovered in six weeks from the date of the first appearance of the symptoms.

Besides these two successful cases I have also had a fatal one. The patient was a young man aged twenty-two years in whom the symptoms supervened upon an injury to the leg received at football.

Barking, Essex.

OrMskirk Cottage Hospitar.-The newly erected Cottage Hospital at Ormskirk was formally opened by the Countess of Derby on Jan. 22nd. It stands on a piece of land between two and three acres in extent, presented by the Earl of Derby, and consists of three pavilions connected by a corridor $55 \mathrm{ft}$. long. The central block contains an operating room, bathroom, and a ward for two beds, while at either end of the corridor there is a ward for three beds. The treasurer said that the hospital, including all the internal fittings and arrangements, cost between $£ 1100$ and $£ 1150$.

\section{de atlitror}

$$
\text { OF }
$$

\section{H O S I T A L P R A C T I C E BRITISH AND FOREIGN.}

Nulla autem est alia pro certo noscendi via, nisi quamplurimas et morborum et dissectionum historias, tum aliorum tum proprias collectar habere, et inter se comparare.-Morasani De Sed. et Caus. Morb. lib. iv. Procemium.

\section{WESTMINSTER HOSPITAL.}

CASE OF ADDISON'S DISEASE TREATED UNSUCCESSFULLY WITH SUPRARENAL CAPSULES.

(Under the care of Dr. W. MURRELL.)

THe treatment of Addison's disease by the administration of the suprarenal capsules of some animal, such as the sheep, has not been extensively tried as yet, but the results obtained so far are not at all encouraging. This case was mentioned as an example of unsuccessful treatment by Dr. Parkinson at a recent meeting of the Clinical Society during a discussion on a paper by Dr. Ringer and Dr. Phear Dr. Ringer gave a summary of recorded cases where similar treatment had been tried; out of nine, five patients had shown improvement, but it could not be said that a sufficient time had elapsed to determine whether the benefit was permanent or not. In two cases no improvement was noted, in one a limited trial of the treatment was given, and in another death followed. Dr. Turney, at the same meeting, referred to another case in which this treatment received a fair trial, but without definite result. Cases of Addison's disease often improve although no treatment is given, so that it is difficult to say that any temporary improrement when the capsules are given is in reality due to them. In this case a most careful trial of the method was carried out, and it is probable that improvement would have resulted had there been any specific action in the capsules which were administered.

A man aged thirty-one years was admitted into Bouverie Ward, Westminster Hospital, on Nov. 15th, 1895, suffering from Addison's disease. Two of the patient's uncles on the mother's side died from phthisis, but apart from this there was no history of that disease. He had always been well fed and had never been much exposed to cold or wet. He fell from a ladder a distance of about fifteen feet, in October, 1894, but was not hurt and experienced no inconvenience from it. He had never been laid up and always led a comfortable and fairly easy life. A bout the beginning of August he noticed that his skin was beginning to grow yellow, but for some weeks before this he had been feeling unwell and had been depressed in spirits. A week later he had a severe attack of romiting, which lasted for a couple of days and was followed soon after by another attack of shorter duration. On admission to hospital he was found to be very weak and was distinctly emaciated. He weighed $8 \mathrm{st} .13 \mathrm{lb}$. and stated that before his illness he had weighed 11 st. He was curiously apathetic and showed but little disposition either for conversation or exertion. The whole body presented an olive or greenish-brown colour, the pigmentation being very marked on the face, hands, abdomen, and in the regions of the axillæ and scrotum. There were two well-marked patches on the mucous membrane of the mouth, one on either side. His appetite was fair, but not so good, he said, as it was formerly. There was no cough, and an examination of the chest showed nothing abnormal with the exception of a little increased resonance over the front of both lungs. The bowels were regular and there was no albumin or sugar in the urine. He was kept under observation and without active treatment for ten days. During that time he had only one attack of vomiting. He lost $4 \mathrm{lb}$. in weight, and in the evening his temperature varied from $99 \cdot 6^{\circ}$ to $100^{\circ} \mathrm{F}$. On the $26 \mathrm{th}$ he was ordered tabloids of extract of suprarenal capsule, one three times a day, each tabloid representing five grains of the fresh extract. 'This treatment was continued for three weeks, and during that time he took sixty tabloids. He suffered a great deal from nausea, and had three bad attacks of vomiting. He lost $3 \mathrm{lb}$. in weight, and there was a distinct increase in the amount of pigmentation. It was thought that possibly the dose might be insufficient, and four tabloids three times a day were ordered, but they so 